\title{
The Root and Governance of Land Corruption from the Perspective of Behavioristics: Based on the Analysis of Four Typical Cases
}

\author{
Gedong Zhu, Youbin Yu \\ School of Government, Beijing Normal University, Beijing, China \\ Email:zhuged93@126.com
}

How to cite this paper: Zhu, G.D. and Yu, Y.B. (2017) The Root and Governance of Land Corruption from the Perspective of Behavioristics: Based on the Analysis of Four Typical Cases. Open Journal of Social Sciences, 5, 124-138.

https://doi.org/10.4236/jss.2017.59010

Received: August 20, 2017

Accepted: September 11, 2017

Published: September 14, 2017

Copyright ( 92017 by authors and Scientific Research Publishing Inc. This work is licensed under the Creative Commons Attribution International License (CC BY 4.0). http://creativecommons.org/licenses/by/4.0/

\begin{abstract}
In recent years, land corruption frequently turns up at various major media and caught the attention of all walks of life. But very few researches on land corruption can be seen. These researches are limited to manifestation and countermeasures of land corruption, which lack depth and systematicity. On this basis, this paper is designed from the behavioral research perspective to study the behavioral rules and characteristics of land corruption. It also discussed the in-depth institutional reasons for land corruption through a three-dimensional system (subject, occurrence part and method of land corruption) and empirical surveys of four typical cases. The conclusion of the study may be useful for a further understanding of the real situation of land corruption.
\end{abstract}

\section{Keywords}

Land Corruption, Case Analysis, Behavioral Research, Institutional Design, Government Governance

\section{Introduction}

Currently, there lacks a widely recognized standard to define the connotation and scope of land corruption. But land corruption has already become the focus of many major news media reports. Many cases involved a large amount of money, multiple departments, multiple positions and a large number of people, which have caused huge social impacts. Land corruption, reform of state-owned enterprises corruption and major engineering project corruption are known as the "Three major corruptions in contemporary China", and were deemed as one of the six major commercial bribes to be settled. According to related statistics of 
Procuratorial Daily, the proportion of land corruption cases increased from $6.43 \%$ in 2000 to $29.14 \%$ in 2013 . Hence, a profound study on land corruption and a fundamental prevention of corruption behaviors are of great significance.

\subsection{Research Overview of Corruption}

The generally accepted definition of corruption refers to the behaviors of civil servants who seek personal gain improperly by using public power with method of actions or lack of actions ${ }^{1}$. Internationally, the research achievements on corruption are extremely abundant, which basically developed with the public policy science arose after World War II and became even more active with the research on Good Governance in recent years. The research perspective also spans across many fields such as economics, politics, sociology, and psychology, etc.

Economics have always been a major theoretical tool for researchers to study corruption. After studying the bureaucrat system of developing countries, institutional economists concluded that: corruption originates from the weakness of current system, which means the bureaucrats destroy the consensus norms because of their self-interests; from the perspective of market and transaction, some scholars deemed corruption as a process of transaction in "public power market" between officials and customers; some scholars also adopted Principle-Agent framework to analyze corruption and market distortion, and the influence of corruption on social welfare, or analyze the relevance between the private and state-owned property rights and the corruption degree from the property rights perspective, or study official's corruption by using Cost-Benefit framework from the perspective of utility and public demands; rent-seeking theory is also a popular econometric tool to study corruption. In recent years, CPI (Corruption Perceptions Index), established by Transparency International, has made remarkable contributions to the study of corruption and is recognized by numerous institutions; The Institutional Economics of Corruption and Reform, written by Johann Graf Lambsdorff who is the research leader of the organization, systematically, comprehensively and objectively summarized and compared the achievements and research methods of the researches on corruption conducted through economic approaches [1].

Meanwhile, the research achievements on corruption from the perspective of other disciplines are also abundant. Some scholars expressed that corruption activities showed the lacking of occupational ethics and integrity in public services, which are the by-products of specific sociocultural environment, administrative power or the development process. From the perspective of public policies, complicated administrative system is also the cause to the corruption. Some scholars even pointed out that corruption is a universal phenomenon of each society, which has a strong continuity. Folklore of Comlption is very common in the social network of some developing countries. Taking bribes becomes the

${ }^{1}$ This definition is originated from The Study Book of Party's Style Honesty Building and Anti-corruption Work. 
only way for low-income civil servants for a living, and this may be accepted as a social consensus by the public [2]. The formation of this social consensus can be also explained by "conformity" and "social pressure" in psychology. Some researchers even deduced the concepts of "moral costs" and "risk illusion" through economic approaches, which enriched the category of corruption studies from the psychological and behavioral perspectives of civil servants [3]. The adoption of psychological analysis tools not only can analyze the logic thoughts and behaviors of individual decisions in the corruption cases, but also can properly explain the occurrence and evolution of frequent corruptions, huge-amount corruptions and group corruptions.

\subsection{Research Overview of Land Corruption}

Currently, there are already some researches on land corruption. The content of the researches mainly includes manifestation of land corruption, causes to corruption, corruption process, consequences and harm of corruption, and measures to handle corruption, etc. Besides, many scholars chose some part of the process that corruption may happen easily, such as land planning, land renting approval, land expropriation, and land transfer, etc. The research methods mainly include zero tolerance theory, cost-benefit theory, principle-agent theory, rent-seeking theory, game theory, interpersonal relationship theory, public choice theory, and institutional economics, etc. [4]-[9].

In general, the research findings on land corruption are not abundant, which is a contrast to the high attention of the society. Besides, most of the researches only focus the introduction of land corruption, analysis of causes, discussion of solutions, or analysis of a specific part of land corruption. Seldom of them can study land corruption from the empirical perspective and grasp the characteristics of land corruption comprehensively. Hence, based on the definition of corruption, this study defined land corruption as: behaviors of civil servants who seek personal gain (through the method of actions or lack of actions) by improperly using public power in land resources and market management. From the behavioral research perspective, the paper studied the behavioral rules and characteristics of land corruption and discussed the in-depth institutional reasons for land corruption through the establishment of a three-dimensional system (subject, occurrence part and method of land corruption) and the empirical surveys of four typical cases, which may be useful for a further understanding of the real situation of land corruption, and raised reasonable governance policy recommendations.

\section{Research Methods and Case Selection}

The difficulty of corruption researches is the comprehensiveness and authenticity of information collection. It is hard to collect all the real information of the corruption in a certain industry or domain. The study of typical and significant cases in a particular area is still of value. Hence, the corruption cases adopted in 
this research are mainly cases disclosed by the Supreme People's Procuratorate and the Supreme People's Court of China, as well as the corruption cases published by Xinhuanet, people.com.cn, and Procuratorial Daily, which are related to land management. The study also adopted case index analysis method to summarize and extract key information from different dimensions to analyze the cases. In the past, case studies often select a single or a few events for analysis, focusing on the case itself, and it is difficult to obtain the common characteristics of certain events, which in turn affect the follow-up analysis. Case index analysis is a method of detailed analysis of each case by constructing a statistical index system, which can better reflect the common characteristics of corruption itself and help to achieve objective and scientific conclusions. Currently, case index analysis method is one of the best methods to solve the asymmetric information of corruption, and an effective research tool to reveal the occurrence rule and development trend of corruption.

In order to increase the authenticity and typicality of the research results, this paper selected four typical cases which are typical and have more detailed information from numerous cases collected. These cases have a large impact in China, in the case involved, the nature of the case, the administrative level of the offender and other aspects of a larger coverage, which increased the randomness of the research samples. Based on the selection of four typical cases, this study established a case analysis index system according to the research objectives, including 2 types of first class indexes, and 19 second class indexes. Then, based on the indexes, the study analyzed the cases one by one, extracted key information and built the analysis texts as shown in Table 1 .

\section{Empirical Analysis}

"Behaviorism" is a genre arose in the early $20^{\text {th }}$ century, which studies administrative phenomenon with the perspectives and approaches of behaviorism. The purport of behaviorism is to study the motivation mode and effect of related personnel from their actual behaviors. According to the research perspective of behaviorism, a complete behavior can be described from six elements as subject, object, occurrence part, method, purpose/motivation, and harm.

From the perspective of behaviorism, land corruption behaviors can be also studied from the six aspects. But the three aspects of subject, occurrence part and method can reflect the behavior nature most. Therefore, this paper selected the three dimensions as corruption subject, occurrence part and method to establish the research framework for land corruption behaviors, then concluded the empirical research results through the index statistics and content analysis of the four typical cases (see Table 2).

\subsection{Subject of Land Corruption Behaviors}

According to the above definition of land corruption, the subject of land corruption behaviors refers to the authority who possess or have influence on land resources and market management. The following part is an empirical study on 
Table 1. Analysis indexes of land corruption cases.

Category
A1 Name
A2 Date of birth
A3 Gender
A4 Education background
A5 Age of corruption started
A6 Age when the crime occurs
A7 Position when the crime occurs
A8 Causes to the crime
A9 Administrative rank when the crime occurs
A10 Whether promoted during corruption
B1 Case property
B2 Time of crime
B3 Time of exposure
B4 Span time
B5 Corruption part
B6 Corruption method
B7 Amount involved
B8 Case disposition
B9 Judgment on charges
Basic information of the case (B)

corruption subject.

\subsubsection{Concentrated Ages of Land Corruption Subjects}

As shown in the four typical cases, the ages of the corruption subjects are mainly ranged from 40 to 50 when the crime started, and 50 to 60 when the crime reported. Generally, 40 - 60 is the age when the corruption subject holds large power. They are in the peak of their career and corruption is easily to happen.

\subsubsection{Involving Large Amounts of Money and Lands with Far-Reaching Influences}

The rareness and non-renewable character of lands fundamentally decided that land management corruption will involve large amounts of money. For the four typical cases, the case of Meng Qingping involved the lowest amount (250,000 yuan), the case of Luo Yaping involved the highest amount (60 million yuan), and the average amount is 16.86 million yuan. This shows that land management corruption usually involves a large amount of money. In addition, personal involvement usually ranged from 1 million to 6 million yuan. The case of Dai Yuejin and Li Jianghua is the most typical. Luo Yaping, a section level official who is also known as the so-called "land grandma", gave full play of her power in land expropriation and approval. She used fake documents to take land compensation and resell land resources. The involved amount is more than 60 million yuan, making Luo Yaping a "giant corrupt official". When this case happed 
Table 2. Basic information of four typical land corruption cases selected.

\begin{tabular}{|c|c|c|c|c|}
\hline Index & Case 1 & Case 2 & Case 3 & Case 4 \\
\hline Name & Luo Yaping & Li Jianghua & Dai Yuejin & $\begin{array}{c}\text { Meng } \\
\text { Qingping }\end{array}$ \\
\hline Date of birth & 1960 & 1963 & 1957 & 1937 \\
\hline Gender & Female & Male & Male & Male \\
\hline $\begin{array}{l}\text { Education } \\
\text { background }\end{array}$ & $\begin{array}{c}\text { High school/secondary } \\
\text { school }\end{array}$ & Graduate & College & $\begin{array}{l}\text { Junior } \\
\text { college }\end{array}$ \\
\hline $\begin{array}{l}\text { Age of } \\
\text { corruption } \\
\text { started }\end{array}$ & 28 & 37 & 46 & 52 \\
\hline $\begin{array}{l}\text { Age when the } \\
\text { crime occurs }\end{array}$ & 48 & 46 & 50 & 61 \\
\hline $\begin{array}{l}\text { Position } \\
\text { when the } \\
\text { crime occurs }\end{array}$ & $\begin{array}{c}\text { Director of Land \& } \\
\text { Resources Bureau of } \\
\text { Shuncheng District, } \\
\text { Fushun, Liaoning }\end{array}$ & $\begin{array}{l}\text { Deputy director } \\
\text { of Jiangxi } \\
\text { Land \& } \\
\text { Resources } \\
\text { Department }\end{array}$ & $\begin{array}{l}\text { Director of Land } \\
\text { Reserve Centre of } \\
\text { Sanmenxia Land } \\
\text { \& Resources } \\
\text { Bureau }\end{array}$ & $\begin{array}{c}\text { Deputy } \\
\text { governor of } \\
\text { Hainan } \\
\text { Province }\end{array}$ \\
\hline $\begin{array}{l}\text { Causes to the } \\
\text { crime }\end{array}$ & $\begin{array}{l}\text { Report from the } \\
\text { masses }\end{array}$ & $\begin{array}{l}\text { Report from } \\
\text { superiors }\end{array}$ & $\begin{array}{l}\text { Report from the } \\
\text { masses }\end{array}$ & $\begin{array}{l}\text { Report } \\
\text { from the } \\
\text { masses }\end{array}$ \\
\hline $\begin{array}{l}\text { Administrati } \\
\text { ve rank when } \\
\text { the crime } \\
\text { occurs }\end{array}$ & Section level & $\begin{array}{c}\text { Deputy } \\
\text { departmental } \\
\text { level }\end{array}$ & $\begin{array}{l}\text { Deputy division } \\
\text { level }\end{array}$ & $\begin{array}{c}\text { Vice-minist } \\
\text { erial leve }\end{array}$ \\
\hline $\begin{array}{l}\text { Whether } \\
\text { promoted } \\
\text { during } \\
\text { corruption }\end{array}$ & Yes & Yes & Yes & Yes \\
\hline $\begin{array}{l}\text { Case } \\
\text { property }\end{array}$ & Interrelated cases & Group cases & Group case & $\begin{array}{l}\text { Individual } \\
\text { case }\end{array}$ \\
\hline $\begin{array}{l}\text { Time of } \\
\text { crime }\end{array}$ & 1988 & 2000 & 2003 & 1989 \\
\hline $\begin{array}{l}\text { Time of } \\
\text { exposure }\end{array}$ & 2008 & 2009 & 2007 & 1998 \\
\hline Span time & 20 & 9 & 4 & 9 \\
\hline $\begin{array}{l}\text { Corruption } \\
\text { part }\end{array}$ & $\begin{array}{l}\text { Requisition approval, } \\
\text { land transfer }\end{array}$ & $\begin{array}{c}\text { Land use } \\
\text { management }\end{array}$ & $\begin{array}{l}\text { Land development } \\
\text { reserve }\end{array}$ & $\begin{array}{l}\text { Land } \\
\text { approval }\end{array}$ \\
\hline $\begin{array}{l}\text { Corruption } \\
\text { method }\end{array}$ & $\begin{array}{l}\text { Embezzle land } \\
\text { compensation funds } \\
\text { and land transfer fees }\end{array}$ & $\begin{array}{c}\text { Illegal } \\
\text { demolition, } \\
\text { illegal land } \\
\text { expropriation, } \\
\text { and illegal } \\
\text { transaction of } \\
\text { certifications }\end{array}$ & $\begin{array}{l}\text { Illegal handling of } \\
\text { land use rights } \\
\text { transfer, illegal } \\
\text { exemption from } \\
\text { public road tolls }\end{array}$ & $\begin{array}{c}\text { Illegal } \\
\text { reissuing } \\
\text { the } \\
\text { instruction } \\
\text { of } \\
\text { expropriati } \\
\text { on } \\
\text { proceedings }\end{array}$ \\
\hline
\end{tabular}




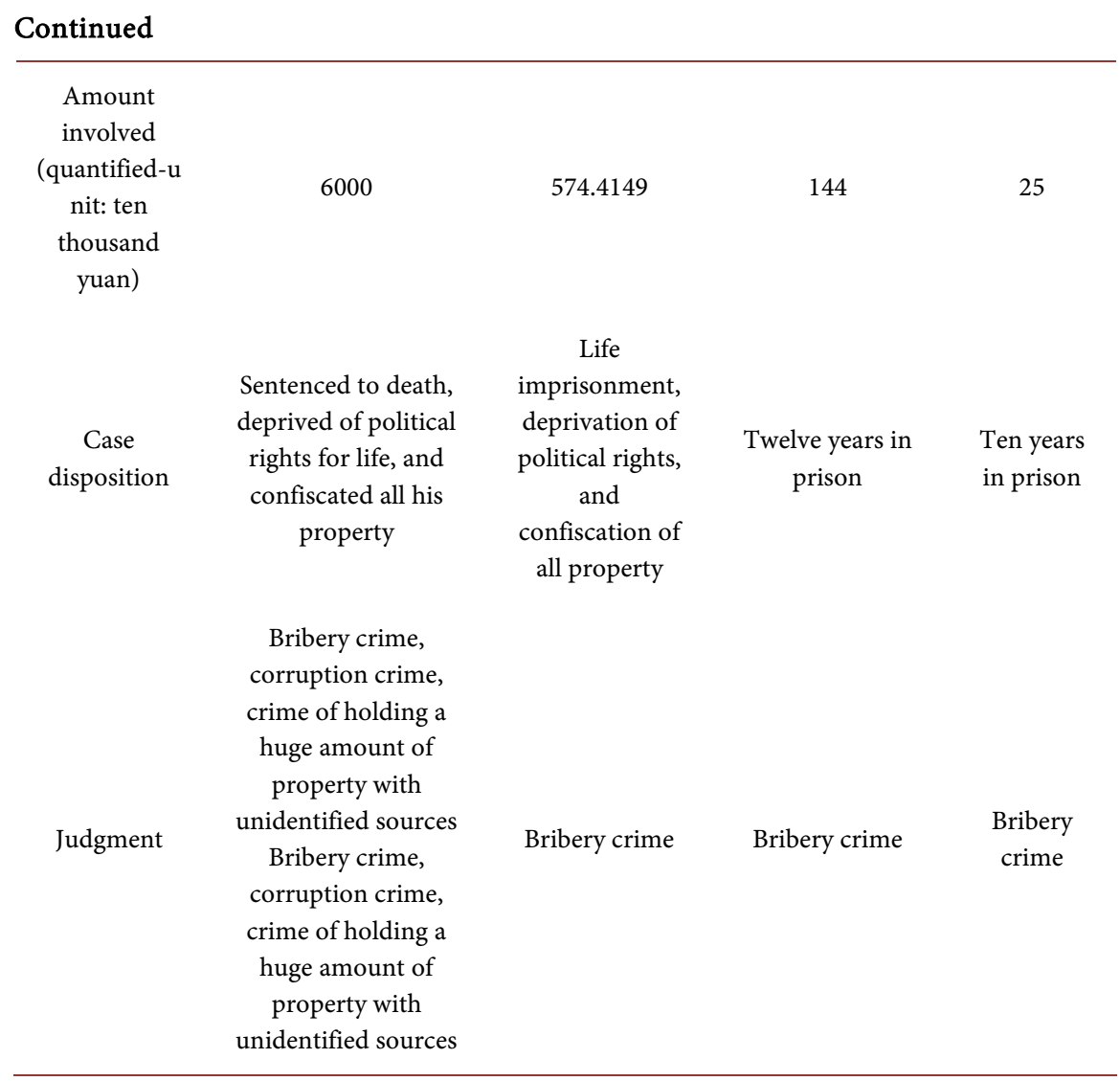

in 2008 , it caused a stir in the society and produced a huge impact.

\subsubsection{Most of Cases Are Group Crimes and Interrelated Crimes, with a Long-Term Latency}

As land management business is complicated and interconnected with each other, it is difficult for a single person to commit official crimes. Besides, the decentralized power of land management system and limitation of laws and regulations make individual official crimes very difficult. Hence, group crimes and interrelated crimes in land system become more and more rampant. Being at the leadership position, corrupt officials gang up for personal interests, turn personal corruption into group corruption, crowd out incorruptible and pragmatic officials, and form a political ecology of "bad money drives out good." In the case of Li Jianghua (deputy director of Jiangxi Land \& Resources Department), 13 officials were placed on file for investigation, including 3 department (bureau) level officials inside and outside the province, and 10 division level officials. In the group corruption case of Dai Yuejin (director of Land Reserve Centre of Sanmenxia Land \& Resources Bureau), 6 high-ranking officials in city-level and county-level land departments used their power to gang up and form a network of corruption, embezzling more than 1.4 million yuan. The corruption chain of group corruption makes it hard to be investigated. The committing of crimes is also becoming more and more concealed. That is why this kind of cases has a long latency. The average latency of the four cases is 10.5 years. The longest is 20 
years, the shortest is 4 years, and the latency of three cases has exceeded 7 years.

\subsection{Corruption Part of Land Corruption Behavior}

\subsubsection{Analysis of Land Corruption Behavior Part and Corruption Risk Points of Corruption}

The main content of land management can be summarized as following seven aspects: formulation of land policies and regulations, cadastral management, land supply and market management, land planning and land use regulation, cultivated land protection and land reclamation, farmland transference and land expropriation, land law enforcement and supervision. Some scholars pointed out that the longer the land industrial chain, the longer the power-for-money deal chain. Power-for-money deals and officer-trader collusions exist in almost each part of the land business, such as the part from land expropriation to land transfer, the part from paying land transfer fees to adjusting plot ratio, the part from land usage registration to property right registration, and the part from the project planning and approval to the project site selection. Any part of land purchase and storage, land demolition, land consolidation, land survey and land planning that are managed by land departments may contain huge rent-seeking space. This paper adopted index analysis method to extract keywords from the four cases, combed and sorted the data, and summarized the major corruptions parts and risk points.

1) Cadastral management

As an important part of land management, cadastral management is the basis for the country's land management as well as the urban and rural land administration and management. Cadastral management can provide information and legal basis for land use. The researches on cadastral management mainly focused the informatization of cadastral management. Seldom scholars made special study on the corruption in cadastral management. In the four examples, the case of Li Jianghua and the case of Meng Qingping are both related with cadastral management. Hence, this paper adopted index analysis method to extract keywords and identify the corruption parts in the cadastral management. According to the analysis on the two cases, the major risk points of cadastral management corruption are reflected as making documents illegally, changing cadastral files, and adjusting land use relations, etc. Cadastral management concerns significant economic interests of the country. If any corruption occurs in this part, huge economic loss will be brought. Li Jianghua, deputy director of Jiangxi Land \& Resources Department, made approvals illegally for more than 10 cases of $100,000 \mathrm{~m}^{2}$ lands, causing a total loss of more than 10 million yuan in land transfer fees and taxes and dues of the country. Meng Qingping, deputy governor of Hainan Province, made instructions twice during his office term to help Zhuang (individual business) backdate, post-register land expropriation proceedings, and get the lands of Po Bo village, Hai Kou. Meng cooperated with others to run the business and gained a profit of more than 250,000 yuan.

2) Land supply and market management 
In 2001, China's land transfer revenue is only 128.6 billion yuan. In 2013, the volume exceeded 4000 billion yuan for the first time, up to 4126.6 billion yuan. Till 2014, the revenue is as much as 4260 billion yuan, which increased more than 30 folds in the past 14 years. The total amount is over 20,000 billion yuan ${ }^{2}$. The audit office of Ministry of Finance performed an audit on the land capital of some areas in 2007, 2009, and 2011 respectively. The report showed that 11 cities illegally used the land transfer fees of totally 8.37 billion yuan in 2008; 11 cities deducted a land transfer revenue of 1.961 billion yuan in disguise in 2010; the land transfer income of 11 cities (67.481 billion yuan) is not properly managed, which is not included in the fund budget management as required, accounting $20.1 \%$ of the total expropriation income; 11 cities have changed the use of land transfer income (totally 5.691 billion yuan). In 2012, totally 9.719 billion yuan of 11 cities and counties were not included in the fund budget management; 12 cities and counties used 1.542 billion yuan of land capital improperly. In addition, according to Ministry of Land and Resources of PRC, 46 cities owed 49.2 billion yuan of land transfer fees in 2013. Under the cover of the shocking data are a huge array of problems. Hence, to find out the corruption part and risk point of land transfer corruption is the key to eradicate land supply corruption. According to the analysis of the keywords extracted from the four cases, land supply and market management are mainly concentrated in land reserve, land supply and land use rights transfer, illegal demolition and expropriation. Of them, land supply is the most serious part. Almost all the corruption cases are concerned with land supply. The main risk is the land supply method. In China, land supply methods mainly include government assignment, tender, auction and listing. Of them, government assignment can reduce the cost greatly. However, the country has specific regulations on government assignment of land. But still many land users slip through the regulations and use various methods to bypass the procedures of tender, auction and listing, and take the land illegally. Besides, there are also a lot of operating space in the procedures of tender, auction and listing, such as to set exclusive conditions to restrict competition, let out land transfer information, black-box operation during the auction part, cheat in contract signing, as well as the most customary and stealthy return, cut, embezzle and defer land transfer fees and various taxes and dues. For example, Dai Yuejin, director of Land Reserve Centre of Sanmenxia Land \& Resources Bureau, acted wrongly for selfish ends and abused his powers to have illegally transacted the use rights transfer of more than $60 \mathrm{mu}$ lands, illegally exempted more than 1.5 million yuan of public road use fees, causing massive loss of national land resources. Besides, land compensation is also the high-incidence part of corruption. Corrupt officials illegally embezzle the land compensation fund to gain huge benefit. Luo Yaping, director of Land \& Resources Bureau of Shuncheng District, Fushun, Liaoning, adopted false compensation and over compensation, cheated in the name of others to gain the compensation of demolition houses, ${ }^{2}$ Sources of data: China Land and Resources Statistical Yearbook. 
stole and sold the demolition house, and embezzled more than 17 million yuan.

3) Land corruption behaviors and methods

The research on land management corruption behaviors and methods is helpful in understanding the crime tactics and effectively prevent corruption behaviors. Currently, land management corruption methods tend to be more diversified, professional, intelligent and convert.

First, the crime tactics are more secret. Corrupt officials used fictional and backdated land expropriation documents to illegally transact state-owned land use rights certificates. They would also use professional land planning methods to make slight adjustment on the plot ratio, making it hard to be noticed.

Secondly, the corruption methods are more convert. Many corruption officials usually conduct various methods to cover their corruption behaviors, such as false receipt for a loan, borrow money to buy houses, buy houses at a low price or resell the houses for personal earnings, invest in real estate companies or cooperate with them, as well as various seeking and accepting bribes in the name of festivals, overseas training, children's weddings, and sick in hospital, etc. For example, Luo Yaping bought 22 housing estates in the name of her relatives to conceal the properties sources of her family.

Thirdly, corruption behaviors are more diversified. Corruption behaviors mainly include direct behaviors and indirect behaviors. The direct method means to intervene related business directly, mainly in cadastral management, land transfer and land approval domains, such as illegal transactions, letting out auction information, instructions in person and issuing instruction notes, etc. Meng Qingping, deputy governor of Hainan Province, made instructions twice during his office term to help Zhuang (individual business) backdate, post-register land expropriation proceedings, and get the lands of Po Bo village, Hai Kou. Meng cooperated with others to run the business and gained huge profits. Indirect methods mainly include implication, inciting, enjoinment, giving orders, organization and coordination, and exerting pressure, etc. Indirect methods are mainly used in obtaining land use rights and land approval, etc.

\section{Further Discussion}

\subsection{Causes to Land Corruption}

Institutional factors are the primary cause of corruption. The land corruption in China has revealed the design and contents problem of the existing land system. Besides, it also reflects the contradiction between the operation and practice of the land system.

\subsubsection{Power Imbalance Caused by Institutional Deficiency}

To analyze the generation mechanism of rampant land corruption, the start should be China's special land system and supervision system. First of all, China adopts urban-rural dual land system. As stated in the constitution, urban lands are state-owned, and rural lands are collective-owned. This means that the new land demands for urbanization and industrialization should be satisfied only by 
national land expropriation, and the lands required by enterprises should be also provided only by the country. Specifically, the local government provides the lands. Because only state-owned lands can be transferred, and the collective-owned lands have the legitimacy only if they are turned into state-owned lands. Current land law also stipulated that the local government can expropriate farmlands according to the requirements of public interests. But the definition of "public interests" is still not specific and clear. This provided a legal protection for the land corruption of local officials to some extent. In addition, the current unreasonable expropriation standard makes the cost of expropriation cost very cheap and expropriation "benefits" very enormous. The local government can obtain huge "land price differences". Hence, the government's monopolization on land supply as stated in relevant laws and regulations provided an institutional space for corrupt officials to use lands to gain illegal benefits.

More importantly, the government acts as a dual role of judge and athletes on land management. As stated in relevant laws, the government is the representative of public interests who makes policies and owns the approval rights, serving as the judge; on the other aspect, the local government holds a large number of land resources who takes part in economic activities as a subject. They can both expropriate lands and sell the lands, serving as the athletes. That's to say, the government has monopolized the approval rights for infrastructure, industry and real estate projects as well as the legal expropriation rights for the lands these projects required. After land expropriation, the local government also holds the pricing rights for the lands. If the enterprises want to get the lands for their projects, they have to seek rent from the government officials. Thus a benefit conveyor chain is formed.

\subsubsection{Impacts of Fiscal Decentralization on Local Economic Behaviors}

According to the tax-sharing system in 1994, the urban and rural land use tax, real estate tax, stamp tax, land value increment tax, and state-owned land compensable use tax are levied by local governments. This makes the fiscal revenue of the local government mainly from various fiscal revenues by transferring land use rights [6]. Lands become another "way of making money" after developing township enterprises.

As a result, the local government considers to increase land fiscal revenue by taking advantage of the deficiencies of China's current land system. According to The Law of Land Administration of China, only the local government has the right to transfer lands, and rural lands can be transferred only when they are transformed into state-owned lands. As a consequence, local government officials usually use their land approval rights and transfer the lands at a low price to "attract investments". Even when low-price land transfer is prohibited by the State Council, they still transfer lands at a low price in disguise by signing land transfer contract first and then returning the land transfer fees or providing fiscal subsidies. The result is that officials and enterprises can transfer benefits to each other, and some enterprises also occupy lands maliciously or resell the 
lands, which eventually lead to land corruption.

\subsubsection{Promotion Incentives Intensified the Interests and Competition of Local Government Officials}

To some extent, Chinese-style fiscal decentralization has stimulated the local government in selling lands, who taking lands as a new "way of making money". However, the appraisal mechanism of the central government on local government officials also exerted great impacts on the economic behaviors of the officials. In another word, the promotion incentives under fiscal decentralization has aggravated the rampant land corruption to a certain degree.

The central government implements target-oriented responsibility system for the appraisal of local government officials, and "one-vote negation system" for indexes of GPD growth rate, family planning and stability maintenance [10]. Under the system with GDP growth rate as the major appraisal index of promoting local government officials, a promotion tournament system was formed. Under such system, local government officials compete with each other to seek high GDP growth rate. To some extent, this phenomenon can explain why fiscal decentralization cannot completely explain the strong motivation of local government in developing economy and transferring lands. Lands are important resources for local government to attract businesses and investments from enterprises. Low-price, large-area and good-location lands are very important parts in local government's strategies of attracting businesses and investments. Under such complicated circumstances, the purpose of local government's transfer of state-owned land use rights is also very complicated. Their corruption behaviors are not only limited to their personal pursuing of money but pursuing of reputation and higher positions.

\subsection{Governance of Land Corruption}

\subsubsection{Reform of Land System; Tighten Constraints on Administrative Power}

First, there should be an end to local government's monopoly of land supply for construction. Rural lands for construction should be given direct access to market on the premise that it is consistent with the overall planning. None-agricultural land rights of construction lands listed in the planning should be allowed to be transferred freely. This way, there will be more supplies of construction lands, thus bringing in a secondary market for construction land. Secondly, a fair and transparent land transaction market should be established; the "bidding, auction and listing" system for productive lands should be improved. At present, the costs of land corruption are relatively low due to information inequity, non-transparent transaction, and irregular procedures. This is a major cause to rampant and all-pervasive land corruption. Therefore, the procedures of "bidding, auction and listing" should be normalized, and perspicuous rules on land transaction should be laid down to promote market operation. Furthermore, it is important to improve the construction of land market and establish a tangible 
land market to prevent land corruption. Thirdly, the land approval system should be improved. Land corruption has close relations with administrative approval. Hence, the lack of constraints and supervision on approval power will sure lead to corruption. In respect to land lease, the administrative approval process should be strengthened and perfect systematic restrictive mechanisms should be established. It is also important to regulate land office's administrative approval power. The service standards, procedures, time limit, and responsibilities should be made public. The public has the right to know the information about land usage, land price and registration. The rights should be balanced; a healthy collective decision-making system should be created. The approval of construction land, the management of land assets, the pricing of land and other important land issues should first be discussed within the land office before a collective decision is made. Lastly, the government should intensify their supervision on land lease and strengthen the supervisory mechanism since the lack of an effective supervisory mechanism is a major cause of rampant land corruption.

\subsubsection{Proper Division of Central and Local Government's Financial Power and Administrative Duties}

First, the existing tax system should be reformed and the allocation proportion of shared tax should be reset to properly increase the proportion of local government (i.e. value-added tax); local governments should be empowered with relevant policy-making authority, allowing them to expand local tax categories and sources to acquire certain amount of money to replenish the fund for public goods. Secondly, local government should strengthen their management of extra-budgetary capital. In the existing tax system, most tax revenues are in the hands of central government, which is a direct cause of local government's extra-budgetary capital expansion and heavy dependence on "land finance". Hence, local government should tighten their controls on this part of extra-budgetary capital to eradicate the source of land corruption. Lastly, the inter-government transfer payment system should be modified. The current tax system is highly centralized; local governments rely heavily on central government's transfer payment when trying to finish their tasks, especially in the central and western regions. Both the vertical and horizontal transfer payment should be reinforced; the proportion of recurrent special subsidies should be reduced while the percentage of general financial subsidies should be increased. Consequently, the interest allocation structure of central and local government can be promoted; the financial power of the government will be proportional to its administrative duties, thus eradicating the internal impetus to make money through lands.

\subsubsection{Establishment of Scientific Political Achievements Appraisal System; Perfection of Officials' Selection and Appointment Mechanism}

At present, the political achievements of government officials are evaluated in line with local GDP growth. Local officials are trying to boost local economy by 
making a profit from lands while ignoring some important expenditure on livelihood issues. Therefore, it is urgent to reform the existing incentive system for local officials and increase some new incentive measures. This way, local officials will be encouraged to pay more attention to local populace and still be responsible for their due missions. Meanwhile, the importance of GDP growth and its related indexes should be weakened. New indexes concerning livelihood and sustainable development should be added to the existing appraisal system. The level of local public service and citizens' satisfaction should also be brought into the appraisal function. The behaviors of officials will not be constrained by political tournaments, and the incentives for officials will be changed. The "vicious" competitions between local governments will eventually become "healthy". In respect to the selection of officials, it is important to change local officials' attitude towards responsibility. Most officials tend to attach great importance to the appraisal of their superior authorities while neglecting the opinions and satisfaction of their subordinates and the populace. Therefore, the officials should not be assigned by their direct superior authority. More channels should be provided for people to express their interest appeals. In addition, local populace should be given more rights, enabling them to form effective constraints on local officials' behaviors through the "vote-by-hand" selection mechanism. These in-depth adjustments can effectively restrain the source of the rampant land corruption, thus gradually eradicating land corruption.

\section{Conclusions and Enlightenment}

Land corruption has become increasingly rampant in recent years. This paper is an empirical analysis of 4 typical cases about land corruption. An index analysis framework is established to analyze each case. In order to study the land corruption behaviors, a "three in one" logic structure is created including corruption behavior subject, behavior part, and behavior methods. Furthermore, the features and laws of land management corruption are discussed to acquire the facts in land management domain.

According to this empirical research, it is found that the behavior subject in land management corruption is a feature to be dense in certain age groups, which has a tendency towards systematization and expansion; besides, group corruption and collapse corruption are very common. As regards the behavior part, land management corruption occurs in specific realm and includes many parts and distinct high-incidence fields (e.g. cadastral management, land supply, and market management). The corruption behavior methods are diversified, specialized, intelligent, and highly covert. The phenomenon of land corruption is actually the performance of irrationality in the current land system, financial system and official incentive system in China. It is necessary for the government and the people to continue to explore and optimize the system design.

But there are still some limitations in the research. More specifically, the reliability of research findings is subject to the size of the samples, and it is impossible 
to include all the features and laws of corruption behavior. Despite these unavoidable deficiencies, this research has presented certain knowledge of land corruption behaviors, indicating substantial research significance.

\section{References}

[1] Wedeman, A. (2007) The Institutional Economics of Corruption and Reform: Theory, Evidence, and Policy. Cambridge University Press, Cambridge.

[2] Montuclard, M. (1960) Herzberg f. mausner b. et snyderman b. b. the motivation to work. Revue Française De Sociologie, 1, 244-244. https://doi.org/10.2307/3319954

[3] Rui, D. and Xiuzhi, Z. (2013) Corruption and Its Prevention in Public Resource Transactions-A Case Study Based on the Analysis and Reflection on Land Corruption. Henan Social Science, 21, 27-32.

[4] Changyi, H. and Nan, S. (2013) Economics Analysis of Corruption in Land Acquisition. Management World, 12, 174-175.

[5] Xiuzhi, Z. and Rui, D. (2008) Research on Land Corruption from the Perspective of Administrative Approval. Business Management Journal, 13, 67-70.

[6] Yu, C. (2014) Fiscal Decentralization, Promotion Incentive, and Power Imbalance-An Analytical Framework for Rampant Land Corruption. Truth Seeking, 7, 67-71.

[7] Hubei, L. and Liang, F. (2014) New Perspective on Land Corruption Prevention: Cost-Benefit Consideration Internalization Zero Tolerance. Journal of Nanchang University (Humanities and Social Sciences), 5, 73-79.

[8] Yunlong, W. (2011) Research on Land Corruption from the Perspective of Cost-Benefit Theory. Theory Research, 35, 26-27.

[9] Liangwen, W. and Jiao, H. (2014) Features and Causes of Land Corruption in China. Old Liberated Area Construction, 24, 11-13.

[10] Li, Z., Xianbin, W. and Xianxiang, X. (2011) Fiscal Incentive, Promotion Incentive and Local Officials' Land Transfer Behaviors. China Industrial Economics, 4, 35-43.

\section{Submit or recommend next manuscript to SCIRP and we will provide best} service for you:

Accepting pre-submission inquiries through Email, Facebook, LinkedIn, Twitter, etc. A wide selection of journals (inclusive of 9 subjects, more than 200 journals)

Providing 24-hour high-quality service

User-friendly online submission system

Fair and swift peer-review system

Efficient typesetting and proofreading procedure

Display of the result of downloads and visits, as well as the number of cited articles

Maximum dissemination of your research work

Submit your manuscript at: http://papersubmission.scirp.org/

Or contact jss@scirp.org 